\title{
Microstructure Evolution and Creep Properties of 2.25Cr-1Mo Ferrite-Pearlite and Ferrite-bainite Steels After Exposure to Elevated Temperatures
}

\author{
Wagner Ferreira Lima $^{a *}$, Glaucio Rigueira ${ }^{a}$, Heloisa Cunha Furtado ${ }^{a}$,Maurício Barreto Lisboa ${ }^{a}$, \\ Luiz Henrique de Almeida \\ ${ }^{a}$ Centro de Pesquisas de Energia Elétrica, Cepel, Eletrobras 21941-911, Rio de Janeiro, RJ, Brazil \\ ${ }^{b}$ Cid. Universitária, Centro de Tecnologia, Bloco F, Ilha do Fundão, 68505 Rio de Janeiro, RJ, Brazil
}

Received: August 15, 2016; Revised: November 22, 2016; Accepted: January 02, 2017.

\begin{abstract}
2.25Cr-1Mo steels are widely used in thermoelectric power plants. Under operational temperatures, their properties degrade due to microstructural changes related to carbide coalescence and stoichiometric transformations. The extent of such microstructural changes is controlled by stress, temperature and time. Therefore, these factors can be used to evaluate damage and as life assessment tools for the individual component. In the past, ferrite-pearlite was the predominate microstructure in commercial $\mathrm{Cr}$-Mo steel products, owing to the well-known methodologies for remaining life assessment based degradation. Currently, the ferrite-bainite microstructure obtained through a more economical route is most commonly used for this steel grade. However, there is no consensus in the literature about microstructural changes that can be used as a degradation pattern for ferrite-bainite steels. This paper compares the aged microstructures and creep properties of ferrite-pearlite and ferrite-bainite $2.25 \mathrm{Cr}$ 1 Mo steels. Aging was conducted at 500,575 and $600^{\circ} \mathrm{C}$ until $2,000 \mathrm{~h}$, and creep tests were performed at $575^{\circ} \mathrm{C}$ under a stress of $100 \mathrm{MPa}$. Microstructural changes were characterized by optical microscopy scanning electron microscopy. Metallographic observations of the ferrite-bainite steel show a more stable behavior at the ageing temperatures and time considered. However, creep tests revealed that the ferrite-pearlite microstructure possesses a better rupture time performance. Carbide size distribution and stoichiometric evolution of the carbides provided by transmission electron microscopy support the creep behavior. These results show that the current techniques for evaluating microstructural degradation of 2.25Cr-1Mo steels must be reconsidered.
\end{abstract}

Keywords: Microstructural degradation, Aging, Creep, Cr-Mo steels, Carbides

\section{Introduction}

Cr-Mo steels are widely used in applications under creep conditions, notably in the petrochemical and power generation industries as pressure vessels, piping, boilers and structural parts. These steels present good resistance to creep and corrosion, high toughness and good weldability, and they have an excellent cost/benefit ratio. At the same time, these materials have two important properties for such applications: a low thermal expansion coefficient and a high thermal conductivity. These factors make Cr-Mo steels very attractive to operate at high temperatures and under low stresses.

The mechanical properties of 2.25Cr-1Mo steel depend on the microstructure, which, in turn, is influenced by the cooling rate from the austenitizing temperature ${ }^{1}$. Commercial grade 2.25Cr-1Mo steel can be processed into different microstructures as ferrite-pearlite, ferrite-bainite, fully bainite and tempered martensite, with the first two being typical morphologies for tube fabrication ${ }^{2}$. A ferrite-bainite microstructure results from a thermo-mechanical processing involving normalization and tempering steps, while the ferrite-pearlite microstructure results from slow cooling rates after austenitization.

\footnotetext{
* e-mail: wagnerf180@gmail.com
}

The studies that estimate the remaining life of a component operating under pressure and at high temperatures are based on the data of the literature for $2.25 \mathrm{Cr}$-1Mo steel concerning microstructural evolution and creep behavior. Although life assessment of aged components operating in power plants and process industries has been widely used, the development of an effective, cost-competitive integrity assessment technology has attracted much attention ${ }^{3}$.

Literature on Cr-Mo steels presents well-established microstructural degradation criteria for a ferrite-pearlite microstructure, such as the Toft and Marsden methodology based on the gradual pearlite spheroidizing and carbide coarsening ${ }^{4}$. However, a similar criterion specific to the ferritebainite microstructure has not been formally published. The ferrite-bainite microstructure does not exhibit a clear change during aging, and sometimes, the hardness values remain as those observed in a new material, which makes its assessment using traditional techniques more difficult to apply ${ }^{5,6}$. This means that the ferrite-bainite microstructure observed by optical microscopy appeared to be more stable, although some degradation was observed. The main feature is the coalescence of the precipitates. This phenomenon captures elements from 
the matrix with a consequent reduction of solid solution hardening ${ }^{5}$. The similarity between both microstructures when degraded was also verified, making it difficult to identify them without previous knowledge of the phase distribution in the new material ${ }^{6}$.

The objective of this paper is to study the behavior of 2.25Cr-1Mo steels with ferrite-pearlite and ferrite-bainite microstructures, aged for different durations and at different temperatures and creep tested at $575^{\circ} \mathrm{C}$ under $100 \mathrm{MPa}$. Samples were analyzed by optical microscopy, scanning electron microscopy (SEM) and transmission electron microscopy (TEM).

\section{Methodology}

Table 1 shows the chemical composition of the steels according to the ASTM A355 standard. Both steels were supplied as tubes (324 mm diameter and $25 \mathrm{~mm}$ wall thickness), and samples were cut in the longitudinal sections. The aging was conducted at 500,575 , and $600^{\circ} \mathrm{C}$ for $100,500,1000$ and $2000 \mathrm{~h}$. After each aging test samples were polished and etched with Nital $2 \%$ followed by observation with optical microscopy and SEM. Precipitates were characterized by TEM using extraction carbon replicas and energy dispersive spectroscopy (EDS). To obtain the extraction carbon replicas, polished samples were etched with Nital $20 \%$ and then carbon coated; after they were crossed out and submitted to Vilella's etchant $(5 \mathrm{ml}$ of clorhidric acid, $1 \mathrm{~g}$ of picric acid and $100 \mathrm{ml}$ ethanol $95 \%$ ) and then immersed in ethanol. The precipitates were identified by EDS analysis by comparing the results with the characteristic spectra of each type of precipitate presented elsewhere ${ }^{6-9}$. The identification was done with the ferrite, pearlite and bainite grains, as well as in the grain boundaries. To compare the mechanical properties between each microstructure, creep tests were conducted on the samples as received. The tests, in accordance to ASTM E-139, were performed at $575^{\circ} \mathrm{C}$ under $100 \mathrm{MPa}$.

\section{Results and discussion}

Figure 1 shows the creep tests curves. The average minimum creep rate was $(4.6 \pm 0.8) \cdot 10^{-4} \% \mathrm{~h}^{-1}$ for ferrite-pearlite steel and $(3.4 \pm 1.3) \cdot 10^{-3} \% \mathrm{~h}^{-1}$ for ferrite-bainite steel. This significant difference results in a higher rupture time, as is clearly observed in Figure 1. The rupture time obtained for ferrite-bainite steel in the present work is in agreement with Watanabe et al ${ }^{7}$.

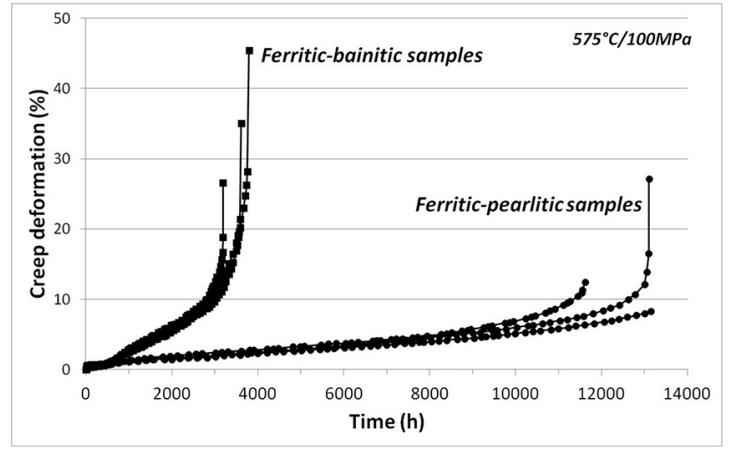

Figure 1: Creep curves for the 2.25Cr-1Mo steels tested. Averages minimum creep rates: $(3.4 \pm 1.3) \times 10^{-3} \% \mathrm{~h}^{-1}$ for ferritic-bainitic microstructure, and $(4.6 \pm 0.8) \times 10^{-4} \% \mathrm{~h}^{-1}$ for ferritic-pearlitic microstructure.

The microstructure evolution during aging was characterized by optical microscopy and Figure 2 shows them for ferrite-pearlite steel in the as received condition and in the more severe $600^{\circ} \mathrm{C}$ for $2000 \mathrm{~h}$, aged steel. Figure 3 shows the microstructure evolution for ferrite-bainite steel in the same conditions as above. The microstructural evolution of 2.25Cr-1Mo steel reveals expected ferrite-pearlite progressive cementite spheroidization until complete pearlite dissolution and, also, precipitation coarsening in the grain boundaries, in agreement with the literature ${ }^{4}$. The ferrite-bainite microstructure, in turn, does not show a remarkable difference between the as received and aged conditions.

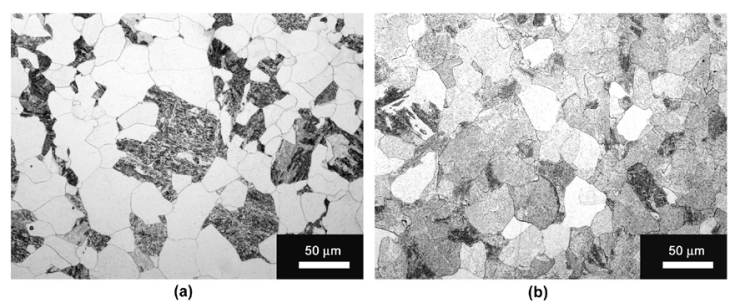

Figure 2: Microstructure of ferritic-pearlitic sample: (a) as received, (b) after $2000 \mathrm{~h}$ at $600^{\circ} \mathrm{C}$.
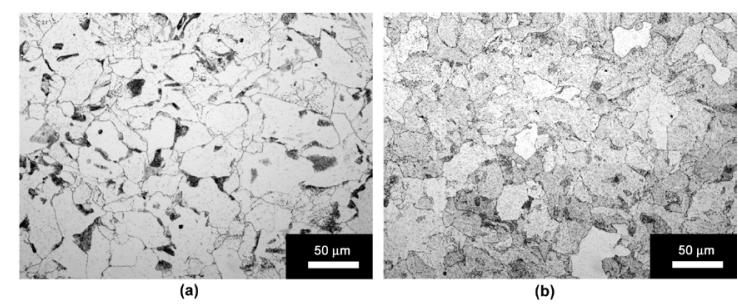

Figure 3: Microstructure of ferritic-bainitic sample: (a) as received, (b) after $2000 \mathrm{~h}$ at $600^{\circ} \mathrm{C}$.

Table 1: Chemical composition (\%wt) of the studied steel and the ASTM A 335 T22 specification.

\begin{tabular}{lccccccccc}
\hline Steel & $\mathrm{C}$ & $\mathrm{Cr}$ & $\mathrm{Mo}$ & $\mathrm{Mn}$ & $\mathrm{S}$ & $\mathrm{P}$ & $\mathrm{Si}$ & $\mathrm{Fe}$ \\
\hline Ferritic-pearlitic & 0.11 & 1.90 & 0.93 & 0.39 & $<0.001$ & 0.009 & 0.21 & Bal. \\
Ferritic-bainitic & 0.11 & 1.91 & 0.94 & 0.38 & $<0.001$ & 0.013 & 0.21 & Bal. \\
ASTM A-335 T22 & $0.05-0.15$ & $1.9-2.6$ & $0.87-1.13$ & $0.3-0.6$ & $0.025_{\max }$ & $0.025_{\max }$ & $0.5_{\max }$ & Bal. \\
\hline
\end{tabular}


Figure 4 shows the microstructural evolution at $600^{\circ} \mathrm{C}$ as a function of aging time, observed by SEM for the ferritepearlite microstructure. The white arrows indicate the carbides along the grain boundaries which coalesce along the time. In the same way, Figure 5 shows the microstructural evolution under the same conditions for the ferrite-bainite microstructure, precipitation coarsening is also signaled by the white arrows. Comparing the images of the $100 \mathrm{~h}$ aging of both microstructures, the coarsening effect in ferrite-bainite is more pronounced, and it is clear that the precipitate distribution in ferrite-pearlite was more effective. That behavior was observed for all ageing samples and it explains the better performance of ferrite-pearlite steels in the creep tests presented at Figure 1.
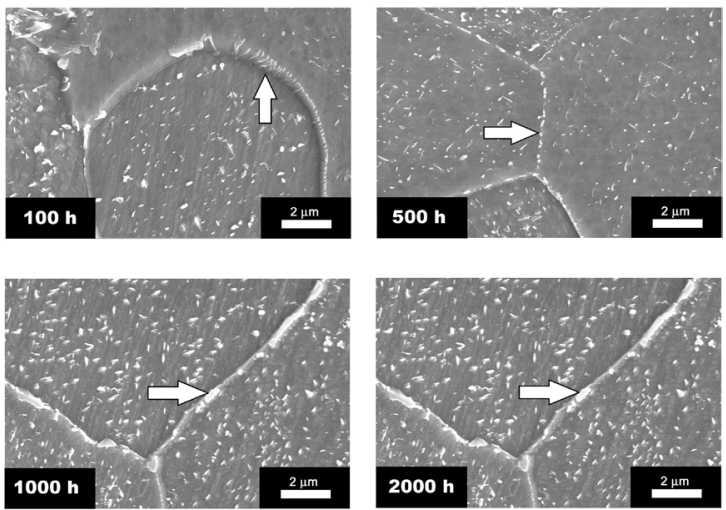

Figure 4: Ferritic-pearlitic steel scanning electron micrographs at $600^{\circ} \mathrm{C}$ and $100,500,1000$ and $2000 \mathrm{~h}$ of aging. The arrows indicate the carbides coarsening effect.
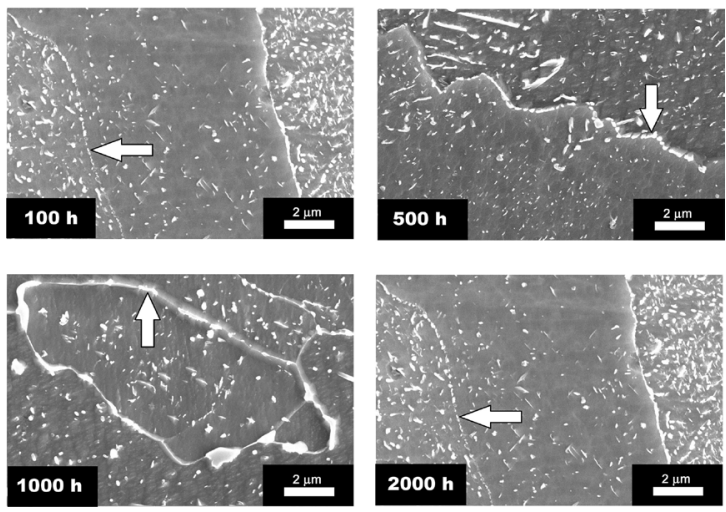

Figure 5: Ferritic-bainitic steel scanning electron micrographs at $600^{\circ} \mathrm{C}$ and $100,500,1000$ and $2000 \mathrm{~h}$ of aging. The arrows indicate the carbides coarsening effect.

Figures 6 and 7 show TEM carbon replicas images of the precipitation present in, respectively, ferrite-pearlite and ferrite-bainite steels aged at $600^{\circ} \mathrm{C}$ for $100,500,1000$ and 2000 hours. Those images were used to select specific areas for the phases characterization. According to the literature ${ }^{8-11}$, carbides present in $2.25 \mathrm{Cr}$-1Mo steels have characteristic EDS spectra, which allow the correct identification of each type. Figure 8 presents the EDS spectra, obtained from the ferrite-pearlite microstructure aged at $600^{\circ} \mathrm{C}$ for 1000 hours, which correspond to the five types of carbides identified in this steel: $\mathrm{M}_{2} \mathrm{C}, \mathrm{M}_{3} \mathrm{C}, \mathrm{M}_{7} \mathrm{C}_{3}, \mathrm{M}_{23} \mathrm{C}_{6}$ and $\mathrm{M}_{6} \mathrm{C}$. Figure 9 shows, for both microstructures aged at $600^{\circ} \mathrm{C}$ for $1000 \mathrm{~h}$, the carbides' identification by colors which enables the observation of their distribution and morphology in the selected regions. The same procedure was adopted for the all aging conditions and for the as received samples and, as result, the precipitation evolution could be studied.
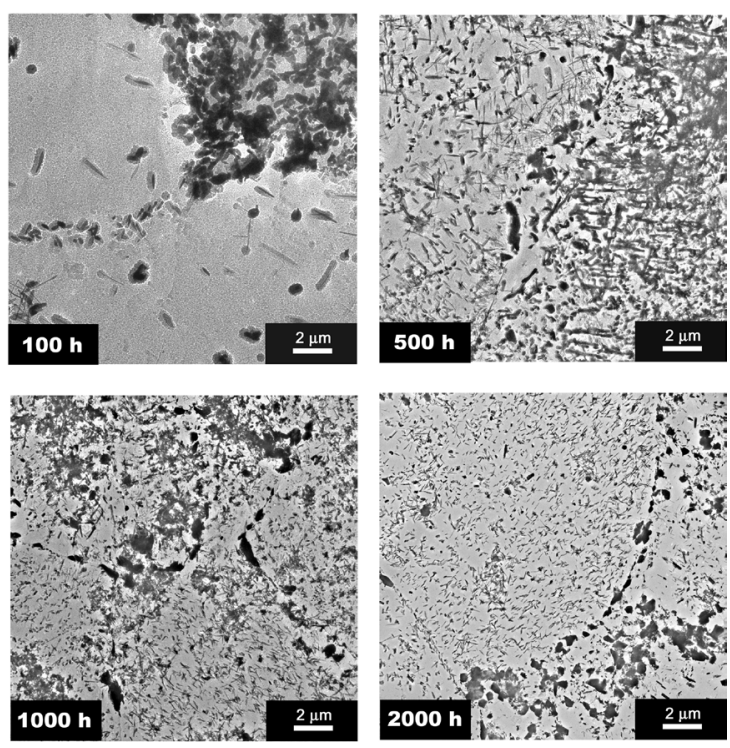

Figure 6: Ferritic-pearlitic steel transmission electron micrographs at $600^{\circ} \mathrm{C}$ and $100,500,1000$ and $2000 \mathrm{~h}$ of aging.
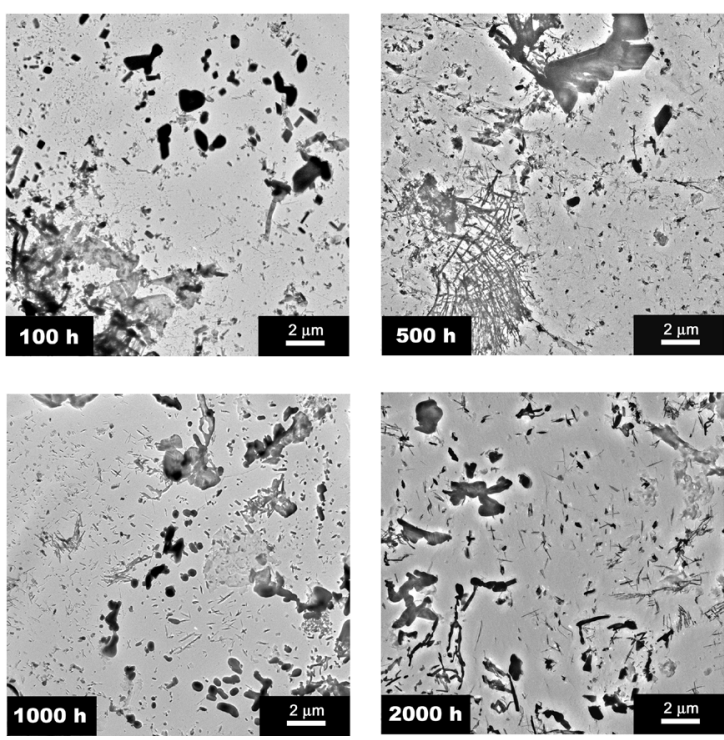

Figure 7: Ferritic-bainitic steel transmission electron micrographs at $600^{\circ} \mathrm{C}$ and $100,500,1000$ and $2000 \mathrm{~h}$ of aging.

The carbide precipitation sequence, shown below, was obtained by characterizing phases in the $2.25 \mathrm{Cr}-1 \mathrm{Mo}$ steels after several aging conditions. 

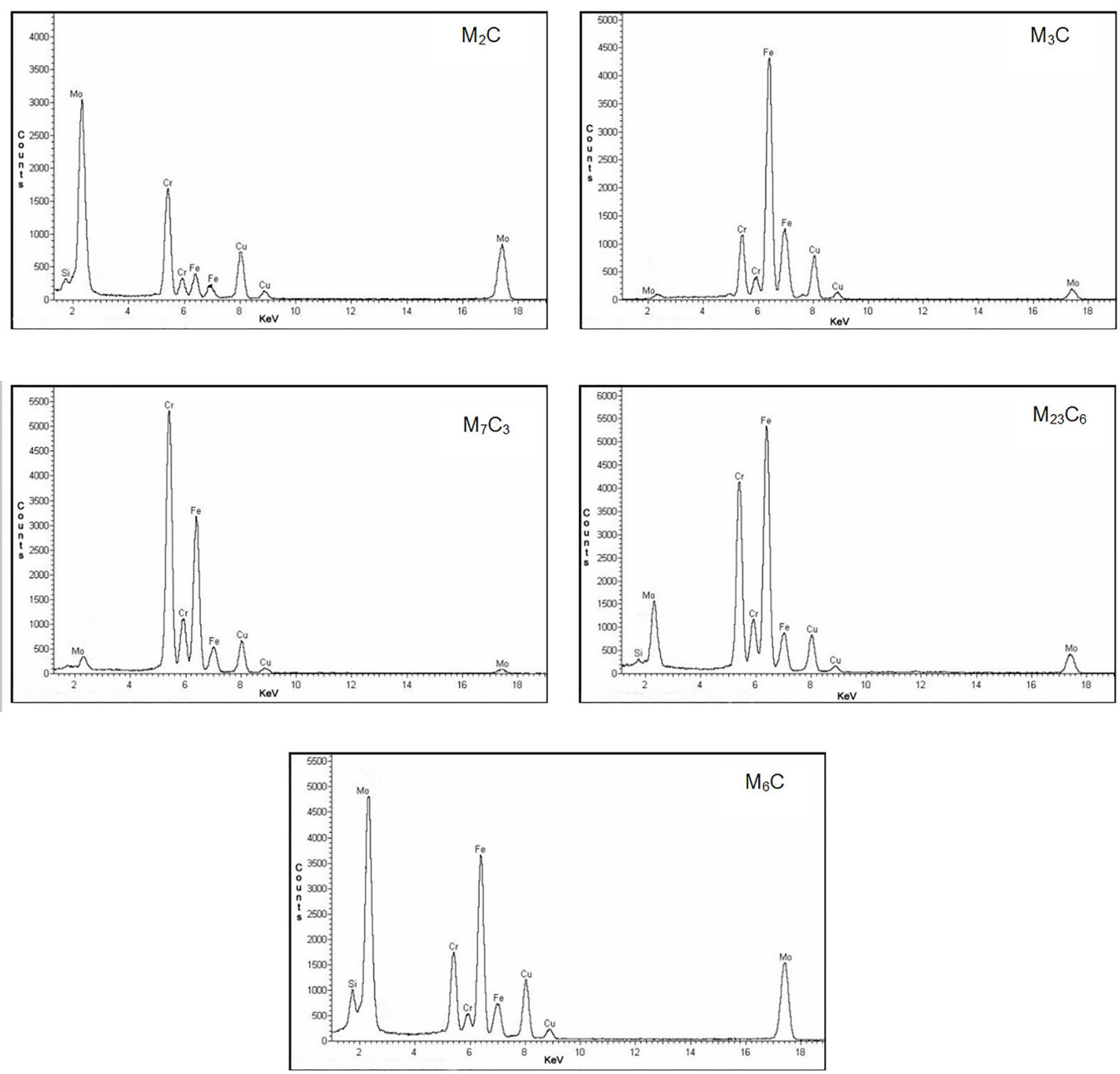

Figure 8: EDS spectra of the carbides identified in the ferrite-pearlite aged at $600^{\circ} \mathrm{C}$ for $1000 \mathrm{~h}$ sample.

For the ferrite-pearlite microstructure:

$$
\begin{gathered}
\mathrm{M}_{3} \mathrm{C}+\mathrm{M}_{2} \mathrm{C}+\mathrm{M}_{7} \mathrm{C}_{3} \rightarrow \mathrm{M}_{3} \mathrm{C}+\mathrm{M}_{2} \mathrm{C}+\mathrm{M}_{7} \mathrm{C}_{3}+\mathrm{M}_{23} \mathrm{C}_{6} \rightarrow \\
\mathrm{M}_{3} \mathrm{C}+\mathrm{M}_{2} \mathrm{C}+\mathrm{M}_{7} \mathrm{C}_{3}+\mathrm{M}_{23} \mathrm{C}_{6}+\mathrm{M}_{6} \mathrm{C}
\end{gathered}
$$

For the ferrite-bainite microstructure:

$$
\mathrm{M}_{2} \mathrm{C}+\mathrm{M}_{7} \mathrm{C}_{3}+\mathrm{M}_{23} \mathrm{C}_{6} \rightarrow \mathrm{M}_{2} \mathrm{C}+\mathrm{M}_{7} \mathrm{C}_{3}+\mathrm{M}_{23} \mathrm{C}_{6+} \mathrm{M}_{6} \mathrm{C}
$$

As observed, the ferrite-bainite microstructure does not present $\mathrm{M}_{3} \mathrm{C}$ phase in any moment of its aging, but it initially presents $\mathrm{M}_{2} \mathrm{C}, \mathrm{M}_{7} \mathrm{C}_{3}$ and $\mathrm{M}_{23} \mathrm{C}_{6}$ phases. The $\mathrm{M}_{23} \mathrm{C}_{6}$ was identified after $1000 \mathrm{~h}$ at 550 and $575^{\circ} \mathrm{C}$ and after $500 \mathrm{~h}$ at $600^{\circ} \mathrm{C}$ for ferritepearlite microstructure. The $\mathrm{M}_{6} \mathrm{C}$ phase was the last identified in both microstructures, but the ferrite-bainite presented it before than the ferrite-pearlite, for all conditions of aging. It is important to say that as deleterious phases, like $\mathrm{M}_{23} \mathrm{C}_{6}$ and $\mathrm{M}_{6} \mathrm{C}$, coalesce, the others decrease their contents, but they are still present even after the most severe aging conditions. That behavior has already been registered in the literature ${ }^{12}$ : the authors observed that as the $\mathrm{M}_{6} \mathrm{C}$ content increased, the $\mathrm{M}_{7} \mathrm{C}_{3}$ content decreased, but, in spite of this correlation, the $\mathrm{M}_{7} \mathrm{C}_{3}$ carbide remained present in all aged samples.

The presence of large $\mathrm{M}_{23} \mathrm{C}_{6}$ carbides for the ferrite-bainite steel in the as cast condition should be noted, especially at the grain boundaries. Although the $\mathrm{M}_{23} \mathrm{C}_{6}$ carbide is a common phase in this class of steel and can be present in a relatively large volume fraction, its presence has generally been associated with a loss of creep resistance. The $\mathrm{M}_{23} \mathrm{C}_{6}$ precipitation removes alloying elements from the matrix, decreasing the solid solution hardening contribution to the creep strength, which corroborates the observed behavior in the creep curves. Moreover, the difference in size and spacing of precipitates present on each microstructure also confirms the behavior of the creep curves. In the ferrite-bainite microstructure, the carbides are larger and more spaced apart, especially in the grain 


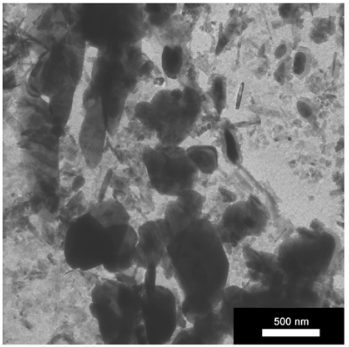

(a)

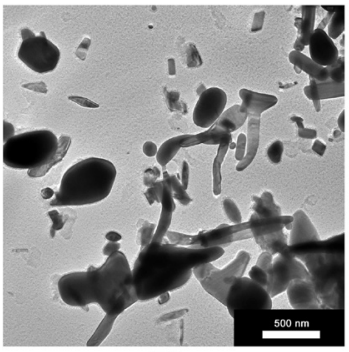

(c)

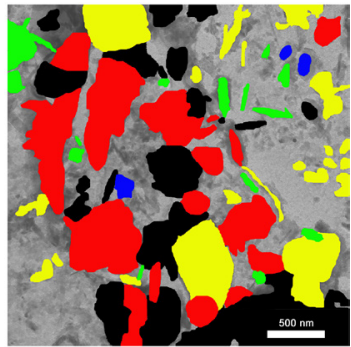

(b)

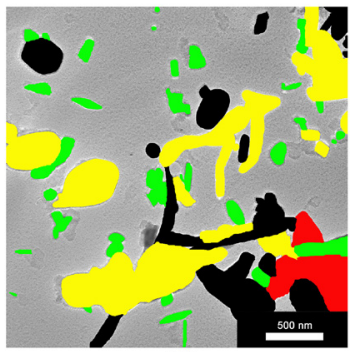

(d)
Figure 9: TEM carbon replicas images of phases identified in the samples aged at $600^{\circ} \mathrm{C}$ and $1000 \mathrm{~h}$ : (a) and (b) ferritic-pearlitic, (c) and (d) ferritic-bainitic. Carbides are identified by colors: $\mathrm{M}_{2} \mathrm{C}$ (green), $\mathrm{M}_{23} \mathrm{C}_{6}$ (black), $\mathrm{M}_{7} \mathrm{C}_{3}$ (yellow), $\mathrm{M}_{3} \mathrm{C}$ (blue), $\mathrm{M}_{6} \mathrm{C}$ (red).

boundaries, as shown in Figures 4 to 7 . The fine precipitation of $\mathrm{M}_{2} \mathrm{C}$ in the ferrite-pearlite microstructure should also be noted. Finally, it can be emphasized that the $\mathrm{M}_{3} \mathrm{C}$ precipitate is still present in the ferrite-pearlite steel even when aged at $600^{\circ} \mathrm{C}$ for $2.000 \mathrm{~h}$, indicating a slower precipitation evolution for this microstructure.

The creep strength of $2.25 \mathrm{Cr}-1 \mathrm{Mo}$ steels depends on inhibiting the dislocation movement. The controlling mechanisms which contribute to it are solid solution hardening and precipitation hardening ${ }^{13}$. It is well accepted that as long as a significant amount of alloying elements remain in the solid solution and the precipitates are finely dispersed in the matrix and grain boundaries, the creep strength will be high. However, temperature and pressure accelerate the precipitates coalescence at the expense of alloying elements in a solid solution in the matrix. These effects are readily apparent to the ferrite-pearlite steels through the spheroidizing process of pearlite grains observed by optical microscopy. For the ferrite-bainite steel, optical microscopy is not capable of distinguishing the microstructural evolution. In this case, it is more effective to analyze the presence of deleterious phases as $\mathrm{M}_{23} \mathrm{C}_{6}$ and $\mathrm{M}_{6} \mathrm{C}$ using TEM.

\section{Conclusions}

Although optical microscopy can indicate the microstructural degradation in ferritic-pearlitic 2,25Cr-1Mo steels, this technique is not sensible to identify the loss of mechanical strength at high temperatures for ferritic-bainitic microstructures. However, TEM analysis can provide useful information on the level of material degradation with pearlitic or bainitic microstructure through carbides stoichiometry and morphology.
Creep tests indicate that ferrite-bainite steel is less resistant than ferrite-pearlite steel. The reasons for this difference are because a ferrite-bainite microstructure presents deleterious phases, $\mathrm{M}_{23} \mathrm{C}_{6}$ and $\mathrm{M}_{6} \mathrm{C}$, earlier and the difference in size and spacing of precipitates.

\section{Acknowledgment}

The authors would to like to thank Vallourec \& Mannesmann Tubes - V\&M do Brasil for supplying the 2,25Cr-1Mo steels and the Electric Energy Research Center (Cepel/Eletrobras) for research development.

\section{References}

1. Kushima H, Watanabe T, Murata M, Kamihira K, Tanaka H, Kimura K. Metallographic Atlas for 2.25Cr-1Mo Steels and Degradation due to Long-term Service at Elevated Temperatures. OMMI. 2007;4(1):1-13.

2. Wang BQ, Geng GQ, Levy AV. Effect of microstructure on the erosion-corrosion of steels. Wear. 1991;151(2):351-364.

3. Chaudhuri S. Philosophy of integrity assessment of engineering components. Materials Science and Engineering: A. 2008;489(1-2):259-266.

4. Toft LH, Marsden RA. Structural processes in creep: special report no. 70. London: Iron \& Steel Institute; 1961. p. 238-244.

5. Bhadeshia HKDH, Honeycombe RWK. Steels: Microstructure and Properties. $3^{\text {rd }}$ ed. Oxford: Butterworths-Heinemann; 2006.

6. Bhadeshia HKDH. Bainite in Steels. Cambridge: Cambridge University Press; 2001.

7. Watanabe T, Yamazaki M, Hongo H, Tabuchi M, Tanabe T. Effect of stress on microstructural change due to aging at $823 \mathrm{~K}$ in multi-layer welded joint of $2.25 \mathrm{Cr}-1 \mathrm{Mo}$ steel. International Journal of Pressure Vessels and Piping. 2004;81(3):279-284.

8. Furtado HC, de Almeida LH, Le May I. Precipitation in 9Cr-1Mo steel after creep deformation. Materials Characterization. 2007;58(1):72-77.

9. Xu Y, Zhang X, Tian Y, Chen C, Nan Y, He H, et al. Study on the nucleation and growth of $\mathrm{M}_{23} \mathrm{C}_{6}$ carbides in a $10 \% \mathrm{Cr}$ martensite ferritic steel after long-term aging. Materials Characterization. 2016;111:122-127.

10. Kuimalee S, Chairuangsri T, Pearce JTH, Edmonds DV, Brown AP, Brydson RMD. Quantitative analysis of a complex metal carbide formed during furnace cooling of cast duplex stainless steel using EELS and EDS in the TEM. Micron. 2010;41(5):423-429.

11. Pilling J, Ridley N. Tempering of 2,25 Pct Cr-1 Pct Mo Low Carbon Steels. Metallurgical Transactions A. 1982;13(4):557-563.

12. de Lima CR, Pinto AL, Furtado HC, de Almeida LH, de Souza MFP, Le May I, Quantitative observations of precipitation in $2.25 \mathrm{Cr}-1 \mathrm{Mo}$ steel exposed to different creep conditions in a power station. Engineering Failure Analysis. 2009;16(5):1493-1500.

13. Pickering FB. Physical Metallurgy and Design of Steels. London: Applied Science Publishers; 1978. 